
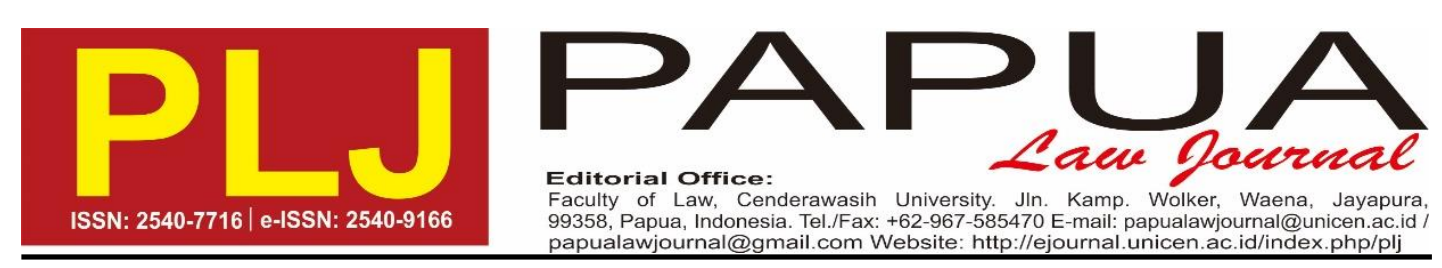

\title{
Rekonstruksi Hukum Lelang Jabatan Struktural Dalam Rangka Reformasi Birokrasi
}

\author{
Yusdar $^{1}$, Irwansyah ${ }^{2}$ \\ ${ }^{1}$ Graduate School, Hasanuddin University, Makassar, Indonesia. \\ E-mail: yusdar.law@gmail.com \\ ${ }^{2}$ Hasanuddin University, Makassar, Indonesia. \\ E-mail: irwansyahrawydharma@yahoo.com
}

\begin{abstract}
Abstrak: Penelitian ini bertujuan mengetahui sejauhmanakah konsep lelang jabatan struktural dapat mewujudkan reformasi birokrasi di Indonesia.Penelitian ini bersifat yuridis normatif.Pengumpulan data dilakukan melalui observasi, dokumentasi, dan kajian pustaka.Data dianalisis dengan menggunakan analisis deskriftif kualitatif.Hasil penelitian menunjukkan bahwa konsep lelang jabatan strukturalmerupakan bentuk dari promosi jabatan yang dilakukan secara transparan dan selektif.Sehingga melalui penerapan konsep lelang jabatan struktural diharapkan mampu menghasilkan pejabat eselon yang berkompeten dimasing-masing bidangnya serta dapat mewujudkan reformasi birokrasi di Indonesia.
\end{abstract}

Kata Kunci: Lelang Jabatan; Reformasi Birokrasi

Abstract: This study aims to determine to what extent the concept of auction structural position can realize good governance in Indonesia. This research was a normative research. Data collected through observation, documentation, and a literature review. Data were analyzed using qualitative descriptive analysis. The outcomes of the research shows that the structural position of the auction concept is a form of promotion that are transparent and selective. So, that through the application of the concept of the auction is expected to produce a structural position echelon competent in the respective field and be able to realize good governance in Indonesia.

Keywords: Auction Office; Bureaucracy Reform

\section{PENDAHULUAN}

Periode ketatanegaraan Indonesia membentangkan fakta normatif, bahwa era reformasi memberi harapan besar (big expectation) akan terjadinya pembaharuan dalam penyelenggaraan negara, untuk dapat mengantarkan negara Indonesia menjadi negara hukum yang demokratis. Hal ini sesuai dengan apa yang menjadi tuntutan reformasi oleh berbagai komponen masyarakat yang sasaran akhirnya 
adalah tercapainya tujuan negara dan cita-cita kemerdekaan sebagaimana yang ditegaskan dalam pembukaan Undang-Undang Dasar Negara Republik Indonesia Tahun 1945 (UUD NRI 1945).

Negara merupakan kesatuan organisasi jabatan-jabatan (ambtenorganisatie) $)^{1}$ yang menjalankan fungsinya berdasarkan tataran organ yang disusun sedemikian sistematisnya agar mampu mencapai tujuan negara secara kolektif dan berkesinambungan. Pencapaian tujuan tersebut diwujudkan melalui tindakan pemerintah yang merupakan penggerak nyata dari negara dalam rangka memenuhi kebutuhan masyarakatnya.

Tidak bisa dipungkiri, semakin kompleksnya kebutuhan masyarakat saat ini juga mendorong semakin berkembangnya tindakan pemerintah yang mampu mewadahi berbagai kompleksitas tersebut. Hal inilah yang dikemukakan oleh Satjipto Rahardjo bahwa hukum tidak berada dalam

\footnotetext{
${ }^{1}$ Ambtenorganisatie secara harfiah berasal dari Bahasa Belanda yang berarti organisasi jabatan-jabatan. Istilah ini dirumuskan oleh Logemann yang mengartikan hakikat negara merupakan kesatuan dari jabatan-jabatan yang tersusun secara sistematis dan menjalankan fungsinya masing-masing untuk mencapai tujuan negara. Lihat, Ridwan H.R. (2013).
}

vacuum $^{2}$ melainkan harus melayani masyarakat. Dalam artian bahwa hukum bukanlah sesuatu yang rigid, melainkan terus bergerak menyesuaikan diri dengan berbagai dinamika kehidupan masyarakat agar senantiasa mampu berjalan dengan efektif dalam memenuhi rasa keadilan bagi rakyat sebagai pemegang kedaulatan tertinggi.

Adanya tuntutan terhadap peningkatan kinerja pemerintahan khususnya yang berkaitan dengan fungsi dan tugastugas pemerintah sangatlah diharapkan oleh masyarakat. Hal tersebut seringkali ditandai dengan maraknya berbagai aksi unjuk rasa yang dilakukan oleh warga masyarakat terhadap kinerja pemerintahan yang selama ini dirasakan seringkali sangatlah mengecewakan, terutama dalam hal menerjemahkan berbagai aspirasi dan kepentingan serta kebutuhan warga masyarakat. ${ }^{3}$

Dalam upaya menjawab berbagai tuntutan tersebut, maka dilakukanlah perubahan-perubahan dalam aspek pemerintahan guna mengoptimalkan

Hukum Administrasi Negara. Jakarta: Raja Grafindo Persada, hlm. 70-71

2 Kata vacuum merupakan bahasa Inggris yang diartikan sebagai pakum, kekosongan, atau ruang hampa; yang dimaknakan sebagai keadaan statis dari suatu hal tertentu.

3 Aminuddin Ilmar. (2013), Hukum Tata Pemerintahan. Makassar: Identitas, hlm 43. 
kinerja pemerintah dalam memberikan pelayanan kepada masyarakat. Salah satu perkembangan atau perubahan mendasar, dilakukan melalui reformasi birokrasi dalam bidang tata kelola pemerintahan di Indonesia. Reformasi birokrasi merupakan sebuah agenda utama dalam era egalitarian saat ini yang semakin menegaskan bahwa Indonesia merupakan negara hukum (rechtstaat) yang mengamanatkan bahwa segala sendi kehidupan berbangsa dan bernegara harus dilangsungkan dengan berasaskan pada ketentuan hukum, bukan atas dasar kekuasaan semata (machtsaat).

Seiring dengan semakin berkembangnya era reformasi saat ini, terlebih setelah melalui empat tahapan perubahan UUD NRI Tahun 1945, terjadi pula perubahan mendasar dalam pola penyelenggaraan pemerintahan di Indonesia. Joko Widodo mengemukakan bahwa paradigma penyelenggaraan pemerintahan telah mengalami pergeseran dari rule government menjadi good governance dan dari sebuah sistem sentralisasi menjadi desentralisasi.

4 Bad Governance berarti tata kelola pemerintahan yang buruk. Istilah ini merupakan perlawanan dari istilah Good Governance (tata
Meskipun demikian, di balik semua upaya yang dilakukan oleh pemerintah dengan berusaha mengefisienkan tataran birokrasi yang ada, termasuk dengan mengadopsi konsep tata kelola pemerintahan yang baik (good governance) tetap belum sepenuhnya dapat memberi jaminan akan terlaksananya suatu tata kelola pemerintahan yang baik. Bahkan masih banyak ditemukan berbagai praktik penyelenggaraan pemerintahan yang menyimpang (bad governance) $)^{4}$ seperti; masih terjadi berbagai tindakan atau perbuatan korupsi, kolusi dan nepotisme dalam pengangkatan jabatan struktural.

Berbagai masalah tersebut salah satunya disebabkan oleh pengetahuan dan pemahaman aparatur pemerintahan terhadap konsep good governance tidaklah begitu memadai. Dalam arti, penerapan terhadap konsep tersebut tidak memperhitungkan sisi kemampuan dan kapasitas dari aparatur pemerintahan, sehingga mengakibatkan pelaksanaan konsep tata kelola pemerintahan yang baik belum berjalan sebagaimana yang diharapkan.

kelola pemerintahanyang baik), yang diartikan sebagai praktik penyelenggaraan pemerintahan yang dilakukan tidak sebagaimana mestinya. 
Penerapan konsep tata kelola pemerintahan yang baik (good governance) tanpa disertai dengan upaya peningkatan kapasitas dan kapabilitas aparatur penyelenggara pemerintahan tentunya tidak akan banyak mengubah wajah penyelenggaraan pemerintahan. Harapan masyarakat akan terlaksananya peran dan fungsi serta tugas pemerintahan secara optimal tetap akan jauh dari apa yang seharusnya diperoleh.

Era reformasi saat ini, upaya untuk mewujudkan sistem pemerintahan yang demokratis, bersih, dan berwibawa telah menjadi prioritas utama bagi rakyat dan pemerintahan Indonesia.Salah satu upaya reformasi itu adalah penataan aparatur pemerintah ${ }^{5}$. Pembaharuan sistem ketatanegaraan dapat diaktualisasikan dengan perubahan paradigma penyelenggaraan pemerintahan dalam pengaturan komprehensif mengenai jabatan pemerintahan yang dapat mengagregasi secara tepat kebutuhan dan kepentingan warga masyarakat. Oleh karena itu, untuk menyem-

5 Sri Hartini, dkk. (2010). Hukum Kepegawaian di Indonesia. Jakarta: Sinar Grafika, hlm 65.

6 The right man on the right position merupakan istilah yang berasal dari adagium The right on the right place yang bermakna penempatan orang yang tepat pada tempat atau purnakan reformasi birokrasi yang dikehendaki, maka selain adanya perubahan konsep dalam struktur pemerintahan, juga perlu dilakukan upaya untuk menempatkan orang-orang atau aparatur yang tepat dalam mengisi jabatan dalam struktur pemerintahan tersebut (the right man on the right position). ${ }^{6}$

Reformasi birokrasi memiliki korelasi yang erat dengan pengaturan secara komprehensif dan sistematis mengenai jabatan-jabatan dalam pemerintahan baik ditingkat pusat, provinsi maupun kabupaten/kota,. Oleh karenanya, untuk mencapai reformasi birokrasi yang tepat, maka diperlukan mekanisme pengisian jabatan-jabatan secara tepat pula.

Hal seperti ini secara tersirat bersesuaian dengan pandangan Plato dalam karyanya yang berjudul The Laws, Plato mengemukakan idenya agar negara diperintah oleh orang-orang bebas dan cendekia, karena Plato menyadari sulitnya mendapatkan orang dengan kualitas itu. Plato kemudian

posisi yang tepat pula. Istilah ini jika dikaitkan dengan pengisian jabatan diartikan sebagai suatu bentuk pengisian jabatan secara ideal dan proporsional dengan menempatkan orang-orang dalam suatu jabatan sesuai dengan kualifikasinya masing-masing. 
berpandangan bahwa negara harus melaksanakan keadilan berdasarkan kaidah-kaidah tertulis. ${ }^{7}$ Pandangan ini mengisyaratkan bahwa pengisian jabatan pemimpin dalam pemerintahan haruslah berdasarkan hukum positif yang berlaku dan mengutamakan rasa keadilan masyarakat secara umum dan menyeluruh, bukan atas dasar keinginan semata sekalipun dengan mengabaikan kualitas yang berusaha diangkat secara subjektif.

Usaha untuk mengatasi problematika pengisian jabatan struktural, juga demi menjamin implementasi hak asasi setiap orang dalam pemerintahan, maka dibuatlah sebuah terobosan tindakan pemerintah dengan melakukan metode pengisian jabatan secara terbuka atau yang lasim disebut dengan istilah lelang jabatan. Sistem pengangkatan jabatan struktural ini di satu sisi bersifat ekstrim tetapi di sisi lain merupakan kebijakan reformis dalam memberantas nepotisme dalam bidang kepegawaian dan untuk mencapai tujuan penempatan persona atau orang pada jabatan sesuai dengan kualifikasinya. Kebijakan ini merupakan sebuah kebijakan reformis mengingat kebijakan tersebut belum lazim digunakan di Indonesia.

Adanya kebijakan yang belum lazim digunakan tersebut, menyebabkan metode atau mekanisme pengisian jabatan secara terbuka ini dalam penerapannya masih menuai berbagai kontroversi atau perdebatan mengingat dasar hukum yang ada dan berlaku saat ini dinilai belum memadai untuk melaksanakan mekanisme tersebut, sehingga dikhawatirkan akan menjadi kebijakan yang "cacat hukum" dan cenderung mengedepankan kekuasaan kepala daerah (machtstaat) semata. Kenyataan ini menunjukan bahwa kebijakan lelang jabatan walaupun memiliki tujuan yang baik, namun dalam tataran implementasinya masih menimbulkan permasalahan terkait mekanisme dan keabsahan atau legitimasi dari sistem pengisian jabatan terbuka tersebut.

Berdasarkan uraian tersebut, maka objek yang akan dikaji lebih lanjut adalah sejauhmana konsep lelang jabatan struktural dapat mewujudkan reformasi birokrasi di Indonesia. 


\section{METODE}

Penelitian ini merupakan penelitian hukum normatif, yakni penelitian yang memberikan beberapa kemungkinan untuk memecahkan beberapa permasalahan yang ada dengan mengumpulkan, menyusun, mengklasifikasi, serta menginterprestasikan datadata yang akan dibahas dan disimpulkan.

Teknik pengumpulan bahan hukum yang penulis gunakan dalam penelitian ini adalah melalui studi kepustakaan yaitu suatu metode pengumpulan bahan hukum dengan cara membaca, menganalisis atau mengkaji buku-buku dan sumbersumber kepustakaan lainya yang berhubungan dengan obyek penelitian.

\section{PEMBAHASAN}

Secara etimologi, kata jabatan berasal dari kata dasar "jabat" yang ditambah imbuhan -an, yang berdasarkan Kamus Besar Bahasa Indonesia diartikan sebagai "pekerjaan (tugas) dalam pemerintahan atau organisasi yang berkenaan dengan pangkat dan kedudukan". 8

8 Poerwasunata, W.J.S. (2003). Kamus Bahasa Indonesia edisi ketiga. Jakarta: Balai Pustaka, hlm 54.

\section{Pasal 28D ayat (3) UUD NRI}

Tahun 1945 mengamanatkan bahwa" "Setiap warga negara berhak memperoleh kesempatan yang sama dalam pemerintahan". Aturan lain yang menyangkut hak pegawai negeri sipil dalam mendapatkan jabatan juga terdapat dalam ketentuan Pasal 72 ayat (2) Undang-Undang Nomor 5 Tahun 2014 tentang Aparatur Sipil Negara (UU Nomor 5 Tahun 214) bahwa setiap pegawai negeri sipil yang memenuhi syarat mempunyai hak yang sama untuk dipromosikan ke jenjang jabatan yang lebih tinggi.

Mengacu pada pembentukan peraturan perundang-undangan, aspek kepentingan merupakan suatu bahan pertimbangan yang amat penting. Sehubungan dengan hal ini Roscoe Pound menyatakan bahwa hukum harus mengharmoniskan kepentingan umum dan kepentingan individual melalui cita-cita keadilan yang hidup dalam masyarakat. Dalam konteks ini, hukum berperan aktif dan sering disebut sebagai fungsi a tool of social engineering. ${ }^{9}$

\footnotetext{
9 Dikutip pada laman website: http://pasca.unhas.ac.id/ojs/index.php/halrev. pada 14 Juni 2015
} 
Sejak diundangkan UU Nomor 5

Tahun 214, maka Indonesia memasuki babak baru dalam sistem, model dan bahkan paradigma birokrasi. Kehadiran undang-undang ini merupakan upaya menjawab berbagai permasalahan yang selama ini dihadapi oleh sistem birokrasi kita yang dinilai banyak bermasalah, sehingga tujuan utama birokrasi (yang dalam hal ini PNS) dalam upaya menciptakan kesejahteraan masyarakat melalui berbagai model dan bentuk pelayanan publik, dinilai telah tercedrai oleh banyak hal, dimulai dengan tidak kedapnya birokrasi dari berbagai kepentingan politik dari para penguasa yang sedang berkuasa, nuansa diskriminasi baik berbasis pada suku, agama maupun ras.

Hal ini dipertegas dalam Peraturan Menteri Pendayagunaan Aparatur Negara dan Reformasi Birokrasi Republik Indonesia Nomor 13 Tahun 2014 tentang Tata Cara Pengisian Jabatan Pimpinan Tinggi Secara Terbuka Di Lingkungan Instansi Pemerintah, dalam lampirannya diatur bahwa:

Pengisian jabatan pimpinan tinggi utama dan madya pada kementerian, kesekretariatan lembaga negara, lembaga nonstruktural, dan Instansi Daerah dilakukan secara terbuka dan kompetitif di kalangan PNS dengan memperhatikan syarat kompetensi, kualifikasi, kepangkatan, pendidikan dan latihan, rekam jejak jabatan, dan integritas serta persyaratan lain yang dibutuhkan sesuai dengan ketentuan peraturan perundangundangan dan dilakukan pada tingkat nasional.

Masih kuatnya cara pandang yang melihat posisi dan jabatan PNS sebagai kelompok orang yang harus dilayani tetapi bukan melayani, bahkan masih kuatnya pemahaman bahwa jabatan tertentu adalah untuk golongan tertentu, adanya penghasilan dan masa depan yang jelas adalah sekian banyak realitas yang sering dan jamak ditemukan dalam masyarakat terutama dalam sistem birokrasi. Tidak mengherankan jika pencari kerja masih menempatkan PNS sebagai minat utama dalam upaya mereka mencari pekerjan.

Adanya posisi dan keadaan yang demikian, maka ekspektasi yang diletakkan pada PNS untuk dapat meningkatkan pelayanan kepada masyarakat sebagai upaya peningkatan dalam proses pencapaian kesejateraan masyarakat masih jauh dari harapan. Alih-alih menciptakan kesejahteraan 
masyarakat justru berbagai persoalan mencuat kepermukaan, seperti masih tingginya angka korupsi dikalangan birokrasi serta rendahnya tingkat kepuasan pelayanan kepada masyarakat, adalah merupakan salah satu indikator atau parameter yang dapat menggambarkan rendahnya kualitas birokrasi.

Pada dasarnya, pengisian jabatan dalam pemerintahan berkaitan erat dengan hak setiap orang, yang merupakan pengejawantahan dari hak politik sebagai bagian dari hak asasi manusia yang harus diakui dan dilindungi oleh negara. Demikian halnya Indonesia, yang mengatur hak tersebut secara mendasar dalam Pasal 28D UUD Tahun 1945 yang secara jelas mengamanatkan bahwa setiap warga negara memiliki kesempatan yang sama untuk turut serta dalam pemerintahan.

Hal ini mengindikasikan bahwa negara sepatutnya memberikan peluang yang setara kepada setiap warga negara untuk mengisi jabatan yang tersedia dalam pemerintahan, termasuk dalam jabatan struktural, yang diwujudkan melalui mekanisme pengisian jabatan yang mampu mewadahi peluang tersebut secara terbuka.
Pengisian jabatan pemerintahan secara yuridis selain diatur dalam Pasal 28 UUD NRI Tahun 1945 juga secara sistematis telah dijabarkan dalam UU Nomor 5 Tahun 2014, Peraturan Pemerintah Nomor 9 Tahun 2003 tentang Wewenang Pengangkatan, Pemindahan, Pemberhentian Pegawai Negeri Sipil; Peraturan Pemerintah Nomor 13 Tahun 2002 tentang Perubahan Peraturan Pemerintah Nomor 100 Tahun 2000 tentang Pengangkatan Pegawai Negeri Sipil Dalam Jabatan Struktural; Surat Edaran Kementerian Pendayagunaan Aparatur Negara dan Reformasi Birokrasi No. 16 Tahun 2012 Tentang Tata Cara Pengisian Jabatan Struktural Yang Lowong di Instansi Pemerintah.

Amanat Pasal 72 ayat (2) UU Nomor 5 Tahun 2014 menyatakan bahwa setiap PNS yang memenuhi syarat mempunyai hak yang sama untuk dipromosikan ke jenjang jabatan yang lebih tinggi. Pengangkatan dalam jabatan didasarkan atas prestasi kerja, disiplin kerja, kesetiaan, pengabdian, pengalaman, dapat dipercaya, serta syarat-syarat objektif lainnya. Usaha untuk lebih menjamin objektifitas dalam mempertimbangkan dan menetapkan kenaikan pangkat dan 
pengangkatan dalam jabatan diadakan daftar penilaian pelaksanaan pekerjaan dan daftar urut kepangkatan.

Peraturan Pemerintah Nomor 9

Tahun 2003 tentang Wewenang Pengangkatan, Pemindahan, Pemberhentian Pegawai Negeri Sipil, menyatakan bahwa Gubernur sebagai Pejabat Pembina Kepegawaian Daerah. ${ }^{10}$ Pejabat Pembina Kepegawaian Daerah Propinsi atau Kabupaten/Kota menetapkan: (a) pengangkatan Calon Pegawai Negeri Sipil Daerah di lingkungannya; (b) pengangkatan menjadi Pegawai Negeri Sipil Daerah bagi Calon Pegawai Negeri Sipi Daerah di lingkungannya, kecuali yang tewas atau cacat karena dinas. Pejabat sebagaimana dimaksud dapat mendelegasikan wewenangnya memberikan kuasa kepada pejabat lain di lingkungannya. ${ }^{11}$

Peraturan Pemerintah Nomor 100 Tahun 2000 Tentang Pengangkatan Pegawai Negari Sipil Dalam Jabatan Struktural menyatakan beberapa persyaratan substansial dalam

\footnotetext{
10 Pasal 1 poin 4 Peraturan Pemerintah Nomor 9 Tahun 2003 tentang Wewenang Pengangkatan, Pemindahan, Pemberhentian Pegawai Negeri Sipil.

${ }^{11}$ Pasal 3 Peraturan Pemerintah Nomor 9 Tahun 2003 tentang Wewenang Pengangkatan,
}

menduduki jabatan struktural sebagai berikut:

1. Berstatus Pegawai Negeri Sipil.

2. Serendah-rendahnya menduduki pangkat 1 (satu) tingkat dibawah jenjang pangkat yang ditentukan.

3. Memiliki kualifikasi dan tingkat pendidikan yang ditentukan.

4. Semua unsur penilaian prestasi kerja sekurang-kurangnya bernilai baik dalam dua tahun terakhir.

5. Memiliki kompetensi jabatan yang diperlukan.

6. Sehat jasmani dan rohani ${ }^{12}$

Disamping persyaratan sebagaimana dimaksud dalam pasal 5 Peraturan Pemerintah tersebut, pejabat pembina kepegawaian pusat dan pejabat pembina kepegawaian daerah perlu memerhatikan faktor senioritas dalam kepangkatan, usia, pendidikan dan pelatihan jabatan serta pengalaman yang dimiliki. Pegawai Negeri Sipil yang diangkat dalam jabatan struktural yang belum mengikuti dan lulus pendidikan dan

Pemindahan, Pemberhentian Pegawai Negeri Sipil.

${ }^{12}$ Pasal 5 Peraturan Pemerintah Nomor 100 Tahun 2000 tentang Pengangkatan Pegawai Negari Sipil Dalam Jabatan Struktural. 
pelatihan kepemimpinan sesuai dengan tingkat jabatan struktural wajib mengikuti dan lulus pendidikan dan pelatihan kepemimpinan selambatlambatnya 12 (dua belas) bulan sejak yang bersangkutan dilantik. ${ }^{13}$

Surat Edaran Nomor 16 Tahun 2012 tentang Tata Cara Pengisian Jabatan Struktural yang Lowong Secara Terbuka di Lingkungan Instansi Pemerintah menyatakan bahwa sesuai Grand Design Reformasi Birokrasi yang dipertajam dengan rencana aksi Program Percepatan Reformasi Birokrasi salah satu diantaranya adalah Program Sistem Promosi PNS secara terbuka. Sehubungan dengan ketentuan sebagaimana tersebut di atas, guna lebih menjamin para pejabat struktural memenuhi kompetensi jabatan yang diperlukan oleh jabatan tersebut, perlu diadakan promosi PNS atau pengisian jabatan berdasarkan sistem merit dan terbuka, dengan mempertimbangkan

\footnotetext{
${ }^{13}$ Pasal 7 Peraturan Pemerintah Nomor 100 Tahun 2000 Tentang Pengangkatan Pegawai Negeri Sipil Dalam Jabatan Struktural

${ }^{14}$ Surat Edaran No. 16 Tahun 2012 Tentang Tata Cara Pengisian Jabatan Struktural Yang Lowong Secara Terbuka di Lingkungan Instansi Pemerintah, hal. 2

${ }^{15}$ Pasal 1 poin 12 Peraturan Gubernur DKI Jakarta No. 19 Tahun 2013 Tentang Seleksi Terbuka Camat dan Lurah
}

kesinambungan karier PNS yang bersangkutan. ${ }^{14}$

Jabatan Struktural yang menjadi objek kajian dalam hal ini Lurah dan Camat. Peraturan Gubernur DKI Jakarta No. 19 Tahun 2013 Tentang Seleksi Terbuka Camat dan Lurah menyatakan seleksi pengisian Jabatan struktural Lurah dan Camat dilaksanakan secara terbuka. Seleksi Terbuka adalah proses pemilihan yang diumumkan secara luas melalui media bagi PNS yang memenuhi syarat untuk diangkat dalam Jabatan Camat atau Lurah ${ }^{15}$. Seleksi terbuka Camat dan Lurah dilakukan dengan prinsip objektif, transparan, dan akuntabel. ${ }^{16}$

Menurut Logemann dalam bukunya yang diterjemahkan oleh Makkatutu dan Pangkerego, jabatan $\operatorname{adalah}^{17}$ :

"Lingkungan kerja awet dan digaris-batasi, dan yang disediakan untuk ditempati oleh pemangku jabatan yang ditunjuk dan disediakan untuk diwakili oleh mereka sebagai

\footnotetext{
${ }^{16}$ Pasal 4 Peraturan Gubernur DKI Jakarta No. 19 Tahun 2013 Tentang Seleksi Terbuka Camat dan Lurah

${ }^{17}$ Logemann, diterjemahkan oleh Makkatutu dan Pangkerego dari judul asli Over de Theori Van Een Stelling Staatsrecht, Universitaire Pers Leiden, 1948, Tentang Teori Suatu Hukum Tata Negara Positif, Ikhtiar Baru-Van Hoeve, Jakarta, 1975, hal. 124.
} 
pribadi. Dalam sifat pembentukan hal ini harus dinyatakan dengan jelas.'

Logemann menghendaki suatu kepastian dan kontinuitas pada suatu jabatan supaya organisasi dalam berfungsi dengan baik. Jabatan dijalankan oleh pribadi sebagai wakil dalam kedudukan demikian dan berbuat atas nama jabatan, yang disebut pemangku jabatan. Apakah pemangku jabatan berwenang mewakilkan jabatan kepada orang lain? Logemann menjawabnya bahwa "dalam hal ini perlu ditempatkan figura-subsitu (pengganti) yang diangkat untuk mewakili jabatan itu dengan sepenuhnya di bawah pimpinan pemangku jabatan”. Inilah yang menurut Logemann disebut dengan pemangku jamak, karena ada pertalian antar jabatan-jabatan seperti itu, tampak sebagai sebagai satu kesatuan.

Secara teoritis, tata cara pengisian jabatan yang baik telah dikemukakan oleh Logemann bahwa bagian yang terbesar dari Hukum Negara (Staatsrecht) adalah peraturanperaturan hukum yang menetapkan secara mengikat bagaimana akan terbentuknya organisasi negara itu.
Peraturan-peraturan hukum itu mengenai:

1. Pembentukkan jabatan-jabatan dan susunannya;

2. Penunjukan para pejabat;

3. Kewajiban-kewajiban, tugastugas, yang terikat pada jabatan;

4. Wibawa, wewenang-wewenang hukum, yang terikat pada jabatan;

5. Lingkungan daerah dan lingkaran personil, atas mana tugas dan jabatan itu meliputinya;

6. Hubungan wewenang dari jabatan-jabatan antara satu sama lain;

7. Peralihan jabatan;

8. Hubungan antara jabatan dan pejabat.

Logemann menunjukkan pentingnya perhubungan antara negara sebagai organisasi dengan pengisian jabatan, oleh karena itu teorinya disebut Teori Jabatan. Adapun pengertian jabatan dirumuskan dalam frasa jabatan negeri, yang diartikan sebagai jabatan dalam bidang eksekutif yang ditetapkan berdasarkan peraturan perundang-undangan, termasuk di dalamnya jabatan dalam kesekretariatan lembaga tertinggi negara, dan 
kepaniteraan pengadilan sebagaimana diatur dalam Pasal 1 ayat (3) UndangUndang Nomor 43 Tahun 1999 Tentang Pokok-Pokok Kepegawaian. Logemann menempatkan "jabatan" dari aspek negara sebagai organisasi otoritas yang mempunyai fungsi yang saling berhubungan dalam suatu totalitas lingkungan kerja tertentu, sehingga negara disebut sebagai suatu perikatan fungsi-fungsi. Negara sebagai organisasi jabatan yang melahirkan otoritas dan wewenang, dan jabatan adalah bagian dari fungsi atau aktivitas pemerintahan yang bersifat tetap atau berkelanjutan. Jabatan muncul sebagai pribadi (persoon) atau subjek hukum, yang dibebani kewajiban dan dijadikan berwenang untuk melakukan perbuatan hukum, akan tetapi untuk melakukan tindakan harus melalui "pejabat" atau "pemangku jabatan". Dalam hal ini harus ada pemisahan mutlak antara pribadi pemangku jabatan selaku "pejabat" dan selaku manusia sebagai Prive.

Dalam rangka memperoleh pemahaman yang lebih luas mengenai

18 Budi. (2014). Pengertian Jabatan. Diakses Melalui http://seoulmate.dagdigdug. jabatan perlu dikemukakan istilahistilah sebagaimana diatur dalam Pasal 1 ayat (3) Undang-Undang Nomor 43 Tahun 1999 Tentang Pokok-Pokok Kepegawaian, yaitu ${ }^{18}$ :

1. Unsur atau elemen, ialah komponen yang terkecil suatu pekerja, misalnya memutar, menarik, menggosok, dan mengangkat;

2. Tugas atau task, ialah sekumpulan unsur yang merupakan usaha pokok yang dikerjakan karyawan dalam memproses bahan kerja menjadi hasil kerja dengan alat kerja dan dalam kondisi jabatan tertentu;

3. Pekerjaan atau job, adalah sekumpulan kedudukan yang memiliki persamaan dalam tugas-tugas pokoknya dan berada dalam satu unit organisasi. Jabatan atau occupation adalah sekumpulan pekerjaan yang berisi tugastugas pokok yang mempunyai persamaan dan yang telah sesuai dengan kesatuan organisasi.

com/pengertian-jabatan/pada tanggal 15 Juni 2015 
Selanjutnya dikutip dari Utrecht dalam bukunya yang berjudul Pengantar Hukum Administrasi Negara Indonesia menyatakan bahwa" "Jabatan ialah suatu lingkungan pekerjaan tetap yang diadakan dan dilakukan guna kepentingan negara (kepentingan umum)"

Jabatan adalah kedudukan yang menunjukkan tugas, tanggung jawab, wewenang, dan hak seorang PNS dalam susunan sesuatu satuan organisasi. Pengertian jabatan dapat ditinjau dari sudut strukturil yang menunjukan secara tegas kedudukan dalam rangkaian jabatan yang ada dalam organisasi, seperti Direktur, Sekertaris, dan dapat ditinjau dari sudut fungsi yang menunjukkan kegiatan-kegiatan yang dilakukan dalam suatu organisasi seperti juru ketik, peneliti, dan juru kesehatan ${ }^{20}$. Pengadaan Jabatan adalah sekumpulan pekerjaan yang berisi tugas-tugas yang sama atau berhubungan satu dengan yang lain, dan yang pelaksanaannya

${ }_{19}$ Utrecht, E. (1986). Pengantar Hukum Administrasi Negara Indonesia. Cetakan keempat. Surabaya: Pustaka Tinta Mas, hlm 71

${ }^{20}$ Definisi Pekerjaan Profesi Jabatan dan Karir.Diakses Melalui http://ilmukritis. wordpress.com /2012/02/28/definisi-pekerjaan- meminta kecakapan, pengetahuan, keterampilan dan kemampuan yang juga sama meskipun tersebar di berbagai tempat.

Di satu sisi sistem lelang ini akan membawa dampak positif karena PNS akan mempunyai peluang yang lebih banyak untuk menduduki jabatan struktural seperti dikatakan oleh Kepala BKD DKI Jakarta I Made Karmayoga bahwa pengisian jabatan melalui mekanisme lelang ini merupakan lompat galah untuk karier PNS, karena dulu sangat kecil kemungkinan PNS dari bidang lain menjadi camat atau lurah. Saat ini melalui mekanisme lelang jabatan diketahui bahwa salah seorang yang lolos menjadi adalah seorang dokter gigi yang sebelumnya menjabat sebagai kepala puskesmas ${ }^{21}$.

Di sisi lain, mekanisme ini menuntut PNS untuk merencanakan serta menggapai kariernya secara mandiri dengan mencari peluang karir di berbagai tempat yang menurut dia mungkin, inilah yang disebut oleh

profesi-jabatan-dan-karir/ pada tanggal 11 Juni 2015

${ }^{21}$ Sumber: http://www.tempo.co/read/news/ 2013/06/27/083491662/Lompat-Galah-KarierPNS-Lewat-Lelang-Jabatan 
Constant D. Beugré ${ }^{22}$ sebagai protean careeratau karir yang bermacamragam atau karir yang berubah-ubah. Walaupun mempunyai dampak positif namun protean career menyimpan banyak jebakan karena jalur karir yang tidak linier dan bahkan bisa menjadi kacau balau.

Menurut Gary Dessler ${ }^{23}$, dalam pengembangan karir pegawai ada tiga hal yang saling berhubungan dan saling terkait satu sama lain yaitu individu pegawai, pimpinan, dan organisasi dimana masing-masing mempunyai peran dalam pengembangan karir pegawai. Peran pimpinan diantaranya adalah memberikan dukungan dan penilaian pengembangan karir, melakukan diskusi dan memberikan dukungan rencana pengembangan karir, sedangkan peran organisasi diantaranya adalah memberikan peluang pendidikan/pelatihan dan pengembangan karir, memberikan informasi karir dan program karir, serta menawarkan beberapa pilihan karir yang sesuai untuk pegawai yang bersangkutan. Jadi dalam pola karir pegawai, organisasi dan pimpinan tidak boleh lepas tangan sama sekali dalam

22 Chapter VI of E-Human Resources Management, Human Resource Portal and the Protean Career: A Three Factor Model, pengembangan karir pegawainya dan membiarkan pegawainya mengembangkan karirnya sendiri. Oleh karenanya bagi sebagian besar PNS lelang jabatan ini bagaikan masuk dalam sebuah ruangan yang gelap gulita yang menyebabkan bingung untuk melangkah, namun bagi sebagian lain merupakan peluang untuk leluasa dalam menentukan tujuan, bahkan banyak pilihan untuk menduduki suatu jabatan dengan mengikuti berbagai lelang jabatan.

Aspek yang dperhatikan dalam pengisian jabatan dengan mekanisme lelang ini dapat dikemukakan sebagai berikut: pertama, konsep keterbukaan sebagaimana dicanangkan oleh Kementerian PAN-RB hendaknya tidak diterjemahkan secara sempit hanya pada saat seleksi/lelang jabatan tetapi konsep keterbukaan ditujukan pada keseluruhan proses manajemen karier; kedua, birokrasi memang harus dijauhkan dari anggapan "bertele-tele", lama, dipersulit, dan sebagainya namun hendaknya tidak mengacaukan struktur birokrasi yang telah diatur menurut undangundang; ketiga, idealnya pengetahuan

Hershey, London, Melbourne, Singapore: Idea Group Publishing, 2005, hlm 58-59. ${ }^{23}$ Ibid. 
dan ketrampilan seseorang berbanding lurus dengan pendidikan seseorang oleh karena itu dalam penerimaan CPNS dicantumkan syarat jenis dan jenjang pendidikan untuk menduduki jabatan tertentu, demikian juga dalam jabatan struktural hendaknya ada jenis dan jenjang pendidikan juga harus menjadi syarat yang menentukan seseorang untuk menduduki jabatan struktural tertentu. Jika semua jenis pendidikan bisa menduduki semua jabatan struktural, dalam penerimaan CPNSpun seharusnya juga menganut hal yang sama.

Pengisian jabatan melalui sistim lelang membawa dampak sebagai berikut:

Pertama, mendapatkan outcome yang positif yaitu terangkatnya PNS yang memiliki kompetensi dan profesionalitas yang memadai sesuai dengan jabatannya sekaligus memiliki hati nurani yang bersih atau paling tidak memiliki rekam jejak yang baik. Mantan Menteri PAN dan RB, Azwar Abubakar mengakui, melalui promosi secara terbuka, akan mendapatkan pejabat struktural yang profesional, memiliki kompetensi tinggi, berkinerja baik, berintegritas, dan sesuai harapan organisasi. Dengan kata lain peme- rintah akan mendapatkan pejabat struktural terbaik diantara yang baik;

Kedua, penggunaan fit and proper test dalam pengisian jabatan menyebabkan persaingan positif akan terbuka. Ada logika yang mengatakan bahwa tidak ada kualitas yang lahir tanpa sebuah persaingan. Adanya persaingan mendo-rong semangat bagi peningkatan kualitas, kinerja dan disiplin PNS. Selama ini PNS yang duduk dalam jabatan tertentu masih banyak yang belum teruji kualitasnya. Di samping itu, budaya birokrasi masih mengindi-kasikan adanya keterkaitan emosional dan ekonomis tertentu dalam mendu-dukkan seseorang dalam jabatan. Keterkaitan emosional seperti adanya kedekatan secara kekerabatan, organi-sasi kemasyarakatan maupun organi-sasi kemahasiswaan sehingga sese-orang mendapat kesempatan untuk dipromosikan dalam jabatan. Keterkaitan secara ekonomis terkait dengan jual beli jabatan untuk mendapatkan keuntungan ekonomi dan politik tertentu.

Ketiga, bagi pejabat Pembina kepegawaian dan pejabat eselon I, II yang berwewenang dalam memberi mandat bagi PNS dalam jabatan tertentu, lelang jabatan dapat ber- 
manfaat untuk menghindarkan diri dari intervensi berbagai pihak yang berusaha menempatkan "orangnya" dalam jabatan strategis di lingkungan masing-masing. Jabatan politik dan kepartaian saat ini memiliki bargaining position untuk mempengaruhi keputusan pejabat publik karena memang atasan pejabat publik secara struktural adalah pejabat politik (menteri, gubernur dan bupati).

Keempat, memperkuat sistem managemen karir berdasarkan merit sistem, yaitu terbuka peluang yang sama bagi setiap PNS untuk meningkatkan karir berdasarkan kompetensi yang dimilikinya. Selama ini terkesan proses rekrutmen PNS dalam jabatan yang dilakukan oleh Baperjakat berjalan kurang objektif dan transparan sehingga PNS malas untuk meraih prestasi tertentu. Ada kesan kemampuan adalah nomor dua, nomor satunya adalah kedekatan dengan pejabat dan faktor nasib.

Kelima, bagi masyarakat, mekanisme ini merupakan kesempatan terbaik untuk membuktikan apakah kinerja pelayanan publik akan semakin baik? Secara teori tentu dapat dikemukakan bahwa mekanisme ini berimplikasi terhadap peningkatan pelayanan masyarakat, namun dalam tataran implementasi masih menunggu pembuktian, yaitu apakah tataran implementasi akan berbanding lurus dengan konsep teoritisnya. Tentu peran aktif masyarakat juga menjadi faktor penting bagi peningkatan kualitas pelayanan publik. Hal ini harus dibarengi dengan upaya pengawasan masyarakat yang jauh lebih intens agar pejabat yang telah diseleksi lebih fokus pada pelayanan masyarakat.

Ada beberapa faktor yang dapat menyebabkan proses assessment tidak berhasil, antara lain:

Pertama, mekanisme seleksi pastilah memakan waktu yang relatif lama dan biaya yang besar. Proses seleksi pastilah melibatkan berbagai lembaga terkait seperti Badan Kepegawaian Negara, Kemenpan dan RB dan Perguruan Tinggi. Selain proses seleksi, tentu harus melewati prosedur standar bagi setiap daerah. Adanya tahapan ini menyebabkan proses asssesmen berjalan relatif lama dan memerlukan biaya penyelenggaraan. Mengingat jabatan eselon di setiap level itu sangat banyak, mulai jabatan eselon I, II, II dan IV yang kosong akibat mutasi atau pensiun setiap bulannya pastilah biayanya juga 
besar.

Kedua, mekanisme seleksi juga tidak menjamin hasilnya baik, mengingat pengalaman bernegara ada saja oknum-oknum yang diberi kepercayaan tertentu kurang amanah. Assessor Centre bisa saja tidak memberi nilai secara objektif karena ada kepentingan tertentu, baik kepentingan diri sendiri maupun kepentingan orang lain secara tidak sah. Budaya birokrasi belum menunjukkan perubahan perilaku yang berintegritas dan layak dipercaya.

Ketiga, keterbatasan aparatur yang professional di bidang tugasnya. Hal ini terkait pelayanan publik yang belum baik, disebabkan oleh kurangnya PNS yang profesional. Kurangnya profesionalitas ini diakibatkan oleh tingkat pendidikan yang kurang memadai, pelatihan jabatan yang terbatas dan sedikit minat untuk belajar secara mandiri. Oleh karena itu, walaupun proses penyaringan dalam jabatan tertentu sudah dilakukan dengan baik namun karena kompetensi dan profesionalitas yang ada masih terbatas maka hasilnya juga kurang memuaskan.

\section{PENUTUP}

Lelang jabatan struktural adalah bentuk dari promosi jabatan yang dilakukan secara transparan dan selektif. Transparan karena dilakukan secara terbuka dan setiap orang yang memiliki syarat administratif berupa tingkat kepangkatan dan golongan, diperbolehkan mendaftarkan diri untuk mengisi lowongan yang tersedia. Selektif karena proses pelaksanaannya dilakukan melalui uji kompetensi ataupun fit and proper test. Lelang jabatan memiliki nilai fositif dalam rangka reformasi birokrasi yaitu untuk merekrut ataupun menempatkan pejabat eselon yang memiliki kompetensi dan profesionalitas yang memadai. Namun disisi lain diharapkan assesmen centre dapat bekerja secara professional. Sebab jika tidak dilakukan secara profesioanl, assesment centre dapat memperpanjang jalur birokrasi sekaligus memperluas kesempatan untuk melakukan KKN. Diharapkan melalui penerapan konsep lelang jabatan ini dapat merubah paradigma masyarakat terkait pengisian jabatan struktural yang selama ini terpola bahwa yang dekat yang dapat. 


\section{DAFTAR PUSTAKA}

Achmad Ali. (2002). Menguak Tabir Hukum. Jakarta: PT. Toko Agung. Aminuddin Ilmar. (2013). Hukum Tata Pemerintahan. Makassar: Identitas.

C.S.T. Kansil. (2005). Sistem Pemerintahan Indonesia.Jakarta: Bumi Aksara.

Utrecht, E. (1986). Pengantar Hukum Administrasi Negara Indonesia. Cetakan keempat. Surabaya: Pustaka Tinta Mas.

Logemann, diterjemahkan oleh

Makkatutu dan Pangkerego. (1975). Tentang Teori Suatu Hukum Tata Negara Positif, (Over de Theori Van Een Stelling Staatsrecht). Jakarta: Ikhtiar Baru-Van Hoeve.

Poerwasunata, W.J.S. (2003). Kamus Bahasa Indonesia edisi ketiga, Jakarta: Balai Pustaka.

Sri Hartini, dkk. (2010). Hukum Kepegawaian di Indonesia. Jakarta: Sinar Grafika.

Chapter VI of E-Human Resources Management, Human Resource
Portal and the Protean Career: A

Three Factor Model, Hershey, London, Melbourne, Singapore: Idea Group Publishing, 2005.

\section{Peraturan Perundang-undangan}

Undang-Undang Nomor 43 Tahun 1999 Tentang Perubahan UndangUndang Nomor 8 tahun 1974 tentang Pokok-Pokok Kepegawaian.

Peraturan Pemerintah Nomor 100 Tahun $2000 \quad$ Tentang Pengangkatan Pegawai Negari Sipil Dalam Jabatan Struktural . Peraturan Pemerintah Nomor 9 Tahun 2003 Tentang Wewenang Pengangkatan, Pemindahan, Pemberhentian Pegawai Negeri Sipil.

Surat Edaran Nomor 16 Tahun 2012 Tentang Tata Cara Pengisian Jabatan Struktural Yang Lowong Secara Terbuka di Lingkungan Instansi Pemerintah.

Peraturan Gubernur DKI Jakarta Nomor 19 Tahun 2013 Tentang Seleksi Terbuka Camat dan Lurah. 